\title{
CHALLENGES AND OPPORTUNITIES OF THE COVID-19 PANDEMIC: A LESSON LEARNT
}

Malissa Maria
Mahmud $^{1}$
(D) Yazilmiwati
Yaacob $^{2}$
(D) Rozaini Ahmad
(i) Nur Izzati
Mustamam ${ }^{4+}$
(D) Md Sairolazmi
Saparman
(i) Noor Syazwani
Ishak
(D) Muhamad Safwan
Mohd A'Seri
(D) Mohamed Nadzri
Mohamed Sharif

Article History

Received: 30 July 2021 Revised: 2 September 2021 Accepted: 6 October 2021 Published: 9 November 2021

\section{Keywords}

Online teaching Learning Technology Covid-19 Pandemic Challenges Opportunities.

\author{
${ }^{\prime}$ Centre for English Language (CELS), Sunway University, Malaysia. \\ 'Email:malissam@sunway.edu.my Tel:+603-74918622 \\ ${ }_{2,3,4, \bar{\sigma}, 6,7,8}$ General Studies Department (GSD), Sunway College, Malaysia. \\ ${ }^{2}$ Email:yazilmiwati@sunway.edu.my Tel: +603-7491 8622 \\ ${ }^{s}$ Email: rozainia@sunway.edu.my Tel: +603-74918622 \\ "Email:nurizzatim@sunway.edu.my Tel: +603-74918622 \\ ${ }^{5}$ Email: sairolazmis@sunway.edu.my Tel: +603-7491 8622 \\ ${ }^{6}$ Email: syazwanii@sunway.edu.my Tel: +603-74918622 \\ Email:safwana@sunway.edu.my Tel: +603-74918622 \\ ${ }^{8}$ Email:nadzris@sunway.edu.my Tel: +603-74918622
}

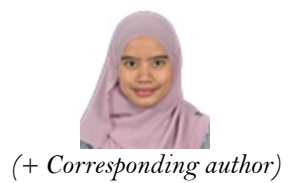

(+ Corresponding author)

\begin{abstract}
COVID-19 has immensely disrupted tertiary education ecosystem. The crisis has compelled numerous unprecedented and accelerated changes. The traditional and conventional way of teaching and learning has completely shifted to fully online. Nonetheless, the trend of integrating technology in the classrooms is not new. This has led to numerous questions and arguments of the existing concepts and theories of traditional education. This phenomenon also provides new opportunities for educational institutions to explore and leverage on the prospects of online modalities, fashioning unique inquiries. Thus, the key purpose of this research paper is to identify the challenges and opportunities encountered by lecturers during the Covid-19 pandemic. The results of the interviews showed that there are some challenges that the lecturers faced; for example, unpreparedness to tackle the new norm of online teaching and learning process, internet connection, and online engagement. The findings from the interview showed that there are opportunities which have emerged from the Covid19 pandemic such as experimenting with numerous digital tools and platforms, employing different online teaching and learning modalities, and commissioning online assessments to support the students' needs and engagement. It is postulated that the findings of the research although may be preliminary, are able to facilitate vital discussions on fashioning best practice guidelines for asynchronous or synchronous modalities post the COVID-19 pandemic.
\end{abstract}

Contribution/ Originality: This study identifies the challenges and opportunities encountered during the Covid-19 pandemic. The findings yielded showed that there are opportunities which have emerged such as experimenting with numerous digital tools and platforms, employing different online teaching and learning modalities, and commissioning online assessments to support the students' needs and engagement. 


\section{INTRODUCTION}

The global crisis due to the spread of Covid-19 has not only postponed the conventional teaching and learning process, but also made it more difficult for teachers because they have to adapt and familiarize themselves with the new living norm which requires the teaching and learning process to be carried out online. The closing of higher learning institutes and schools throughout the country has created massive problems to the teaching and learning activities and long-term effects to educational sector. This current situation has created a challenge for the education institutions around the globe to ensure students' learning can be continued without having to attend to any learning institutes.

Digital, flexible and interactive-based teaching and learning process should have been implemented before Covid-19 strikes. This is because this kind of learning that uses information and communication technologies (ICT) including portable devices such as laptops and smartphones as well as internet connections is the trend for current generation (Lau, Chiu, Ho, Lo, \& See-To, 2017; Yew \& Jambulingam, 2015). In a meta-analysis research encompassing robust sample from year 1980 to 2015, Mahmud (2018) concurred that comprehensive commendation for technological integration to be blended with the face-to-face modality, surpassing the traditional classroom. In fact, the majority of the students in higher learning institutes nowadays can be categorized as Generation Z (GenZ) (Szymkowiak, Melović, Dabić, Jeganathan, \& Kundi, 2021). This generation lives in technology world since the beginning. Most of them search and for information via the internet and share on various social media platforms. They are also more attracted to digitalize, flexible, creative and interactive learning process (Lai, 2011). Therefore, the teaching and learning method for Gen-Z should be transformed in parallel with expectations in order to generate and retain their interest. Furthermore, the existence of modern technologies nowadays has allowed the teaching and learning activities to be carried out anywhere or anytime. The availabilities and conveniences enabled by social media platforms have led to learning processes to not only be confined by physical classroom settings, but beyond ubiquitous technological architypes to enrich the teaching and learning experience (Mahmud, Ramachandiran, \& Ismail, 2016). What was initially and widely embraced as a tool for social networking, the concept that social media is an effective tool for educational purposes has been acknowledged. A research was conducted to assess learners' attitudes and perceptions online peer assessments and collaborative learning environment designed via Facebook whereby the findings promote the use of Facebook as part of learning instructions (Mahmud \& Wong, 2018).

Due to the recent Covid-19 pandemic, online teaching and learning process has become a necessity, no longer an option. This has also forced educators to optimize and utilize the technology at their disposal as tools and platforms for teaching and learning activities. In addition to that, educators were also forced to quickly create an education environment that is both innovative and highly technological. Due to this issue, educators have to face various challenges, one of them is students' unpreparedness for online teaching and learning process. A study done by Chung, Subramaniam, and Dass (2020) on 399 students of higher learning institutes all around Malaysia suggested that among the challenges that the students faced are, their unpreparedness to do online learning due to lack of control, self-directed learning and online communication efficiency. Besides that, there are also students who faced poor internet connectivity and limited Wi-Fi issues. According to Kebritchi, Lipschuetz, and Santiague (2017) not all students are ready for online classes because it requires high self-motivation and self-directed from the students. Therefore, educators who act as online instructors should be prepared to help these students in using technology as learning medium and assist students with internet connectivity problems by providing pre-recorded classes for them. This view was supported by Northey, Bucic, Chylinski, and Govind (2015) who mentioned that various teaching and learning modes like social media, live conferences, as well as pre-recorded lectures were deployed wherein the situation has appeared as an opportunity for students to consume and instructors to diversify via flexibility on the delivery and timing of online learning. 
Besides all the challenges, the Covid-19 crisis has also provided some opportunities of its own. It has allowed the educators to teach without the conventional restrictions of time or place. A study done by Muthuprasad, Aiswarya, Aditya, and Jha (2021) on 307 students in one of the higher learning institutes in India discovered that the majority of the students required more flexible timing for online learning. This is due to the fact that some of the students live in rural areas where there are constant internet connectivity problems. Flexible timing on online learning allows these students to find for locations with better internet connections to study. Online learning also allows students to join in on classes whenever or wherever they are. On top of that, the Covid-19 situation has also forced educators to learn new online teaching and learning techniques and methods. According to Dubey and Pandey (2020) teachers and lecturers must be more proactive in mastering new technologies for the survival of teaching and learning process. In planning for the online class activities, educators have to ensure that students give $100 \%$ commitments to their classes. Ali (2020) suggested that online learning is more closely related to students nowadays. This is because youngsters are more technologically-savvy and more exposed to social media. Online learning allows them to be more motivated to learn, provided that the lecturers are able to engage with their students during online teaching and learning process effectively. Furthermore, E-Assessment should be suited for students' situations to allow the students to complete their tasks properly. Students prefer online classes with prerecorded classes and quizzes at the end of the pre-recorded classes, to improve the effectiveness of the teaching and learning process (Muthuprasad et al., 2021).

In reality, online teaching and learning has become a trend to today's generation. A meta-analysis research finding revealed that the use of technology in the context of teaching and learning facilitate the attainment of learning outcomes (Mahmud, Ubrani, \& Foong, 2020). Be it during the crisis of Covid-19 or after, online teaching and learning has to be continued to ensure the survival of teaching and learning process. Next, the suggestions for education institutions after the Covid-19 crisis are to provide sufficient training for all academic staffs in order to enhance their skills and abilities in mastering the online teaching and learning techniques. According to Dhawan (2020) training programs for teachers need to be developed in order to help them adapt to the changes and to help them to understand the future of education system and also to identify the suitable tools to ensure the learning process can be carried out smoothly. According to Dhawan (2020) there are several issues that the universities have to take care of in order to continue with online teaching and learning process such as, security features, availability and condition of laboratories, internet speed, internet access, digital literacy level of beneficiaries. On top of that, the institutions must provide clear and accurate guidelines in order to effectively implement and execute E-teaching and learning as outlined by the Malaysian Qualifications Agency (Rahim, 2020).

Covid-19 has posed not only unique challenges but also tremendous potential for numerous opportunities in regards to General Studies subjects. Similar to few university programs and courses, the incorporation of online learning in General Studies Department, Sunway University over the last 10 years, while debatably extensive, still remain at an infancy stage, relatively decelerate to obtain prevalent traction, especially at the micro level. This is possibly due to the student-centred deliveries to the subjects that emphasize the needs for thoughtful practices, actual engagements, and experiential approaches. Traditionally, these approaches are synonymous with face-to-face instructions in which 60\% ratio is accounted for physical class (Morris \& Liguori, 2016). Moreover, even though abundance of researches on online learning have been established, little is known concerning the repercussions of online learning in the context of General Studies subjects in Malaysia, with even less is known within the context of challenges and opportunities faced among the academics of online learning amidst the Covid-19 pandemic. At this juncture, the ability to effectively deliver and teach online is completely different assumed by the broad spectrum of variables involved, which inform the pedagogical considerations.

The objectives of the establishment of the General Studies Department of Sunway College (KL) Sdn Bhd are aligned with the objectives suggested by the Malaysia Qualifications Agency (MQA) which are to produce 
graduates who are skilful which allow them to effectively take part in the society. Hence, the objectives of the general studies subjects are as follow:

i. To coordinate Compulsory Subjects with General Studies Subjects in higher learning institutes.

ii. To promote nation-building.

iii. To enhance and expand soft skills.

iv. To reinforce and expand knowledge in Malaysia.

v. To apply soft skills.

These objectives have been further divided into 4 segments $(\mathrm{U} 1-\mathrm{U} 4)$ :

i. U1: The appreciation of philosophy, values and history in Islamic and Asian Civilizations, Ethnic Relations, Malaysian Studies 1, 2 and 3 and Malay Language Communication 1 and 2 for international students.

ii. U2: The enhancements of soft skills in National Language A.

iii. U3: The expansion of general knowledge of Malaysia in Islamic Studies and Moral Studies.

iv. U4: Practical society management skills in Community Services (Malaysia Education Ministry, 2016).

All these subjects from U1 to U4 are considered as main subjects in the General Studies Department. All subjects which are offered by the General Studies Department are compulsory university subjects, and the number of students who enrolled in each subject is very large. The challenges for the lecturers in the General Studies Department before the transition to online learning was managing multiple number of classes, large number of students and grading students' coursework which takes a long period of time. In 2019, the General Studies Department has made some changes from $100 \%$ face-to-face classes to blended learning and eventually to completely online on $28^{\text {th }}$ of March 2020 during the beginning of the Movement Control Order (MCO). The transition to online learning and using E-Learn as Learning Management System has provided the lecturers with a few advantages such as using pre-recorded classes and summative assessments to lessen the burden of lecturers. Instead of having to teaching for 3 hours in the regular classroom settings, lecturers are able to divide the class to 1.5 hours live class and 1.5 hours of pre-class. Besides, the online assessment management has really helped the lecturers with the marking of students' course works because they are done automatically by the system.

Based on the phenomenon above, the main purpose of this research is to identify the challenges faced by the lecturers of the General Studies Department within the online teaching and learning contexts and the opportunities that are available while conducting online classes especially during the Covid-19 pandemic. Next, the suggestions from the lecturers of the General Studies Department for other educators and education institutions on how to further improve online teaching and learning process in the future. This is because even after Covid-19 has ended and students are allowed to go back to their respective schools and universities, online learning should be continued and cannot be separated from the students. Therefore, for the survival of the teaching and learning process post Covid-19, there are several suggestions by various researchers such as, Dhawan (2020) stated that, online learning must be continued because online learning is very beneficial in the times of crisis-like situations, for instance manmade disasters, natural disasters or even pandemic such as Covid-19. Besides that, educators must improve their skills in building relationship between teachers and students through online platforms. There is a need to create a balance between technology and pedagogy in order to transition courses into digital content for example, specific training needed including training in teaching methods (Keengwe \& Georgina, 2012).

\section{METHODOLOGY}

This research uses a qualitative method where purposeful sampling was utilised in which potential participants who represent the group to be studied. Seven (7) lecturers of the General Studies Department, Sunway University were interviewed on the challenges, opportunities and eventually, suggestions to educators and institutions of online teaching and learning process. The objective of the interview method is to understand the situation faced by the researchers. According to Burns and Groove (2014) and Cardano (2020) the use of qualitative design is suitable 
for a research when it involves the observations of an individual or unit, a group of people, family, a class, school, society incident or culture. A research should focus on a subject that has a certain criteria or feature that can be studied (Nelson, 2017; Walby \& Luscombe, 2017; Welch, 2018). The findings from the interview was analysed using adapted guidelines, specifically the trustworthiness criteria developed by Nowell, Norris, White, and Moules (2017) and Lincoln and Guba (1985). This research uses the semi-structured interview method because the research method is flexible, thus allowing the respondents to explain and elaborate on the topic probed by researchers.

The General Studies Department has 15 academic staff which consist of 10 full time staff and 5 part-timers. Among the subjects that are taught by the lecturers of the General Studies Department are, Islamic and Asian Civilization (TITAS), Ethnic Relations, Malaysian Studies 1, 2 \& 3, Communication Malay Language 1 \& 2 , National Language A, Moral Education, Islamic Studies and Community Services. All of these subjects are compulsory subjects that has been set by the Malaysian Qualifications Agency (MQA) for all university students in both public and private higher learning institutes. All lecturers of the General Studies Department have more than 2 years of experiences using the E-Learn as Learning Management System (LMS). For this research, the researchers adapted convenient sampling method and 7 lecturers of the General Studies Department was approached to obtain stipulated information regarding the challenges and opportunities confronted, as well as suggestions for other educators and educational institutions on the use of online teaching and learning method post Covid-19. The online interview sessions were conducted via video conferencing from February 12 to 17,2021 using semi-structured interview questions specifically designed to inquire about the circumstance wherein consent was acquired from the lecturers prior the interview session. Below are the interview questions:

1. Demographic: genders, age, marital status, education level, career experience as lecturers and duration of experience in using E-Learn as a teaching and learning tool.

2. The challenges faced while carrying out the online teaching and learning process.

3. The opportunities learned while carrying out the online teaching and learning process.

4. Suggestions for educators.

5. Suggestions for institutions.

\section{RESULTS AND DISCUSSION}

The next sub-sections comprise of analyses obtained from the study. The first one is the respondents' demographic, followed by the findings which are divided into four themes which are, (1) Challenges, (2) Opportunities, (3) Suggestions for Educators and (4) Suggestions for Institutions. The findings are delineated based on the responses collected, following the sequence of Respondent $1-4$ and the corresponding discussions.

Table-1. Respondents' Background.

\begin{tabular}{l|c|c}
\hline Demographic & Item & Results \\
\hline \multirow{2}{*}{ Gender } & Male & $3(43 \%)$ \\
\hline \multirow{2}{*}{ Age } & Female & $4(57 \%)$ \\
\cline { 2 - 3 } & $30-40$ years old & $5(71 \%)$ \\
\cline { 2 - 3 } Marital status & $>40$ years old & $2(29 \%)$ \\
\hline \multirow{2}{*}{ Education level } & Married & $5(71 \%)$ \\
\cline { 2 - 3 } & Single & $2(29 \%)$ \\
\hline \multirow{2}{*}{ Teaching experience } & Master & $6(86 \%)$ \\
\cline { 2 - 3 } & PhD & $1(14 \%)$ \\
\hline Experience using e-learn & $<5$ years & $2(29 \%)$ \\
\cline { 2 - 3 } & $5-10$ years & $3(42 \%)$ \\
\cline { 2 - 3 } & $>10$ years & $2(29 \%)$ \\
\hline
\end{tabular}




\subsection{Respondents' Demographic}

Table 1 shows the profiles and background information of the seven respondents. The respondents consist of 3 male and 4 people aged 30 and above. The education level of all respondents is at least Master's Degree and all of them have at least 5 years of experience as lecturers. All respondents also have more than 2 years of experience using E-Learn as their teaching tools.

\subsection{Analysis of Challenges Faced by the Lecturers of the General Studies Department while Handling Online Classes}

Four respondents have given their inputs on the challenges that they faced during the Covid-19 crisis. The first respondent stated that:

"A number of students were not prepared to undergo online classes. This is due to the fact that education institutions were abruptly closed and the teaching and learning method was changed too suddenly from face-to-face to completely online."

\subsubsection{According to the Second Respondent}

"Internet connectivity problem has always been an issue for both lecturers and students. The learning process was affected due to the unstable internet connection. Some of the academic staff of the General Studies Department have to come to the university during the Movement Control Order (MCO) to unsure their live class can be carried out more smoothly."

\subsubsection{The Third Respondent Said}

"The lecturers and students took quite a while to familiarize and adapt to the new norm and also to master the new online teaching and learning method."

\subsubsection{The Fourth Respondent Stated that}

"The main challenge is to gain the attention and engagement from the students, especially in a big class with a huge number of students."

The findings stated above support the research done by Chung et al. (2020) and Coman, Țîru, MeseşanSchmitz, Stanciu, and Bularca (2020) which stated that some of the students were not ready for online learning due to the lack of control, self-directed learning and online communication efficacy. Students and lecturers were not prepared for this sudden change to online teaching and learning process, but they still tried to find strategies to adapt and meet new challenges. Students are found to be mentally and physically unprepared to face this situation. A study by Aziz, Shafie, Lee, and Ashaari (2020) found that students are less prepared to face new norms such as online learning and this has affected students psychologically. Apart from that, the internet problem is also an obstacle for students because some of them live in rural or inland areas. The learning place is also not conducive because of the noisy and cramped environment.

As evidently suggested by Windhiyana (2020) she said that students in Indonesia also experienced the same problem. Internet connection becomes a major problem to online learning when the instability of the internet network causes students to not be able to access the classroom well and difficult to understand what has been taught by the teacher.

According to Azizan and Nasri (2020) there are four challenges that students have to face during the pandemic, namely unstable internet problems, unskilled lecturers, and lack of knowledge related to applications in implementing online learning as well as two-way communication problems between students and lecturers. Lecturers are not able to attract attention and communicate well with students. In addition, another challenge is the lack of parental support in helping children cope with online learning which causes students to be unable to focus during learning sessions. This support the research done by Hasin, Daud, and Alias (2020) which stated that some 
students were unable to focus during online learning sessions due to interference from their surrounding environment.

\subsection{Analysis of Opportunities Gained by the Lecturers of the General Studies Department from Managing Online Teaching and Learning Process}

Four respondents have provided their inputs on the opportunities gained during the Covid-19 crisis.

\subsubsection{The First Respondent Stated That}

"Online teaching and learning do not have any restrictions on space, time and place as it is very flexible. It also saves a lot of time and cost as lecturers and students do not have to go to the campus and back. The learning process can be carried out at the comfort of their own homes."

\subsubsection{According to the Second Respondent}

"The Covid-19 crisis has opened some new opportunities for the lecturers to find, learn and apply new techniques for the online teaching and learning process."

\subsubsection{The Third Respondent Said}

"Covid-19 crisis has allowed the lecturers to learn how to use the E-Learn as Learning Management System to their full potential in order to ensure all students give their 100\% commitment to their classes."

\subsubsection{The Fourth Respondent Stated that}

"This crisis has provided the lecturers with the opportunities to rearrange their online assessments to suit current situation to help the students to understand and complete their assessments more easily and effectively.”

Muthuprasad et al. (2021) found that online learning requires flexible timing. This is because, students who live outside the city usually have internet connection problems. In this context, flexible timing allows them to look for locations with good internet connections in order to study. Furthermore, according to Ali (2020) online teaching and learning is more closely related to current students. The current generation especially the Gen-Z has higher inclination to use internet to find information and even socialise. Thus, online learning can potentially be employed, in particular during the unprecedented crisis to ensure on-going teaching and learning. One of the findings stipulated is the opportunities for online assessment to be customized to suit the students' circumstance, Rahim (2020) outlined several characteristics of online assessment, such as achieving the subjects' learning outcomes to balance between summative and formative online assessments. For example, online assessments necessitate imperative factors such as the formatting (multiple choice questions, essays) as well as the platforms of deployment.

In summary, based on the yielded findings, it can be observed that online learning has numerous benefits for both students and lecturers. Covid-19 has led to the opportunity to rethink the existing approaches of technology. Previously, online learning was only part of the long term, but it became a necessity during the covid-19 pandemic. According to Handayani (2020) she said that online learning is very practical and flexible. It becomes very practical because the lecturer and students can interact well and students can ask questions directly to the lecturer without embarrassment. Online learning also becomes very flexible as classes can be done anytime and anywhere with no time limit. Ibrahim and Subari (2021) said that online learning can still be used despite the improvement of pandemic. In fact, it has opened a new avenue for lecturers to explore various online learning applications. This is also supported by Nordin, Hashim, and Latib (2021) who found that online learning is seen to have greatly helped lecturers in becoming more creative and opened space for lecturers to explore more depth about online teaching. 
3.4. Analysis of Suggestions for Educators Post Covid-19 in Transforming the Online Teaching and Learning Technique

There were 4 respondents who provided inputs on the suggestions for educators post Covid-19.

\subsubsection{The First Respondent Stated That}

"Online teaching and learning must be continued even after the Covid-19 crisis has ended. This is because, online learning has become a trend nowadays. Students can study on a flexible schedule regardless of time and place. The full 100\% online learning or the traditional face-to-face learning should be changed to half online learning and half faceto-face learning after this pandemic."

\subsubsection{According to the Second Respondent}

"Educators must join many training courses to further improve their skills in using technology as tools for online teaching and learning process, and also learn new online techniques to build relationship between educators and students.”

\subsubsection{The Third Respondent Said}

"Educators must be prepared physically, mentally and emotionally in understanding the functionalities of the tools used so that they can carry out their online classes more efficiently. For example, in the General Studies Department, we use the E-Learn as Learning Management System. Therefore, lecturers must know how to set for their classes, monitor students' attendances for pre-classes and live classes, prepare quizzes, assignments and final examinations, and the various other functions to ensure the classes run smoothly."

\subsubsection{The Fourth Respondent Stated That}

"An institution should only use one platform only as to not create any confusion among students. If each lecturer uses different platforms to teach their own classes, students will be confused and it will be harder for them to join the online classes. For example, if 4 different subjects use 4 different learning platforms, students will find it more difficult to learn and master each platform."

Multiple studies can be used to support these views from the respondents. For example, according to Dhawan (2020) the E-Learn learning method has its own strengths. It can help both lecturers and students during difficult times. The online teaching and learning methods can be adjusted by the lecturers to suit the students. Lecturers can use audio, video or text aides to replace the face-to-face classes and use live classes to get immediate feedbacks, ask queries and learn more interestingly. Keengwe and Georgina (2012) stated that, the use of technology and pedagogy must be in balance in order to transition into digital contents. Specific trainings needed include training in teaching methods, media and technical supports, and course design support offered by instructional designers, technicians, graphic designers, teaching assistants, and librarians. Faculty members are invited to participate in the training workshops such as BETA in order to ensure they have prerequisite technology skills and familiar with the chat and discussion tools. Aside from that, according to Azizan and Nasri (2020) technology can become the bridge for lecturers to exchange and share knowledge with their students.

Moreover, lecturers should also be prepared with digital devices as well as financial stability in order to carry out online learning classes during the pandemic period. On top of that, based on a study by Gunawan, Suranti, and Fathoroni (2020) the use of technology as Learning Management System (LMS) must be managed properly to help both the lecturers and the students during the online teaching and learning process.

3.5. Analysis of Suggestions for Institutions Post Covid-19 in Transforming the Online Teaching and Learning Technique

Four respondents have given some inputs on the suggestions for education institutions post Covid-19. 


\subsubsection{The First Respondent Stated That}

"Education institutions must provide exercises and training not only for the lecturers but also the students in order to improve their abilities and skills using technology as teaching and learning platforms."

\subsubsection{According to the Second Respondent}

"Education institutions must identify effective tools and use the standardize tools for the Learning Management System so that the online teaching and learning process can be carried out smoothly without confusing the students."

\subsubsection{The Third Respondent Said}

"Clear and accurate preparation of guidelines must be done to ensure the effectiveness of E-teaching and learning and to achieve the PLO and SLO as outlined by the Malaysia Qualifications Agency (MQA).”

\subsubsection{The Fourth Respondent Stated That}

"The role of academic leaders in an institution is to create a significant change to achieve the teaching and learning objectives."

The views of the respondents mentioned above were further supported by several researchers such as Coman et al. (2020) that stated education institutions must provide practices and training for their lecturers to help them adapt to changes, to assist them to understand current education trend that involves online environment. Besides that, students' feedback is also important for the institutions to provide support from other aspects such as the use of suitable tools, providing (audio, video and text) aides and looking for strategies to park their interests and keep them focused during courses. Meanwhile, Dhawan (2020) suggested that, an institution should choose suitable tools for the online teaching and learning process. The tools should cover security features, availability and condition of laboratories, internet speed, and internet access, digital literacy levels of the beneficiaries, and so on. According to Rahim (2020) university leadership must identify the baseline infrastructural and human resource preparedness, decide on and clearly communicate a strategy for information and communications technology (ICT) integration, organize faculty development activities in ICT integration and online assessment and ensuring adequate technical support for educators when using online assessment tools.

\section{CONCLUSION}

The results of the interviews revealed that there are some challenges that the lecturers of the General Studies Department faced; for example, unpreparedness of the lecturers to tackle the new norm of online teaching and learning process, internet connection, and online engagement. The findings from the interview showed that there are opportunities which have emerged from the Covid-19 pandemic such as experimenting with numerous digital tools and platforms, employing different online teaching and learning modalities, and commissioning online assessments to support students' needs and engagement. From the study, some suggestions from the findings were discovered whereby online approaches are deemed as apt to be part of teaching and learning process even after Covid-19 has passed. Moreover, it was discovered that institutions should identify suitable learning management system tools for the educators and students in order to ensure the effectiveness of online teaching and learning in line with the standard and quality as outlined by the Malaysian Qualifications Agency (MQA). Since this is a qualitative-based research in which the findings were attained from interview sessions, which may pose some limitations, it is recommended that future researches garner more data from more respondents through quantitative means. Finally, it is postulated that the findings of the research although may be preliminary, are able to facilitate vital discussions on fashioning best practice guidelines for asynchronous or synchronous modalities post the COVID-19 pandemic. 
Funding: This study received no specific financial support.

Competing Interests: The authors declare that they have no competing interests.

Acknowledgement: This is a collective research effort between the General Studies Department (GDS) academic staff and Associate Professor Dr Malissa Maria Mahmud from the Centre for English Language Studies (CELS), Sunway University. We would like to thank Associate Professor Dr Malissa Maria Mahmud for her mentorship and tremendous support, and also Ms $\mathrm{Ng}$ Beng Lean for the encouragement provided for GSD academic staff to participate in the Seminar on Internal-External Quality Assurance (SieQA) 2021.

\section{REFERENCES}

Ali, W. (2020). Online and remote learning in higher education institutes: A necessity in light of COVID-19 pandemic. Higher Education Studies, 10(3), 16-25. Available at: https://doi.org/10.5539/hes.v10n3p16.

Aziz, A. R. A., Shafie, A. A. H., Lee, U. H. M. S., \& Ashaari, R. N. S. R. (2020). Strategies for the development of aspects of selfwell-being to cope with academic stress during the Covid-19 outbreak. Malaysian Journal of Social Sciences and Humanities, 5(12), 16-30.

Azizan, S. N. C., \& Nasri, N. M. (2020). Teachers' perspectives on online learning through the home based learning (HBL) approach during the COVID-19 pandemic. PENDETA: Journal of Malay Language, Education and Literature, 11(1), 4657.

Burns, E., \& Groove, W. (2014). Research method. Ergonomics, 32(3), 237-248.

Cardano, M. (2020). Defending qualitative research: Design, analysis, and textualization (pp. 1-176). London: Routledge.

Chung, E., Subramaniam, G., \& Dass, L. C. (2020). Online learning readiness among university students in Malaysia amidst COVID-19. Asian Journal of University Education, 16(2), 46-58. Available at: https://doi.org/10.24191/ajue.v16i2.10294.

Coman, C., Țîru, L. G., Meseșan-Schmitz, L., Stanciu, C., \& Bularca, M. C. (2020). Online teaching and learning in higher education during the coronavirus pandemic: Students' perspective. Sustainability, 12(24), 10367. Available at: https://doi.org/10.3390/su122410367.

Dhawan, S. (2020). Online learning: A panacea in the time of COVID-19 crisis. Journal of Educational Technology Systems, 49(1), 522. Available at: https://doi.org/10.1177/0047239520934018.

Dubey, P., \& Pandey, D. (2020). Distance learning in higher education during pandemic: Challenges and opportunities. International Journal of Indian Psychology, 8(2), 43-46.

Gunawan, G., Suranti, N. M. Y., \& Fathoroni, F. (2020). Variations of models and learning platforms for prospective teachers during the COVID-19 pandemic period. Indonesian Journal of Teacher Education, 1(2), 61-70.

Handayani, L. (2020). Advantages, constraints and solutions of online learning during the covid-19 pandemic: An explorative study at SMPN 3 Bae Kudus. Journal of Industrial Engineering \& Management Research, 1(2), 15-23.

Hasin, A., Daud, Z., \& Alias, N. (2020). Challenges of implementing online Tajweed learning in PKP phase: A study at the faculty of Quran and Sunnah Studies, Universiti Sains Islam Malaysia. Paper presented at the Proceedings 3rd International Seminar on Islam and Science 2020: (SAIS 2020) Covid-19: Implication, Impact and Solution (SAIS 2020).

Ibrahim, R., \& Subari, A. M. (2021). The wisdom perspective of online edication during the covid-19 outbreak: The wisdom perspective of online edication during the covid-19. Journal of Quran Sunnah Education ES Special Needs, 5(1), 46-63.

Kebritchi, M., Lipschuetz, A., \& Santiague, L. (2017). Issues and challenges for teaching successful online courses in higher education: A literature review. Journal of Educational Technology Systems, 46(1), 4-29. Available at: https://doi.org/10.1177/0047239516661713.

Keengwe, J., \& Georgina, D. (2012). The digital course training workshop for online learning and teaching. Education and Information Technologies, 17(4), 365-379. Available at: https://doi.org/10.1007/s 10639-011-9164-x.

Lai, K. W. (2011). Digital technology and the culture of teaching and learning in higher education. Australasian Journal of Educational Technology, 27(8), 1263-1275. Available at: https://doi.org/10.14742/ajet.892. 
Lau, K. P., Chiu, D. K., Ho, K. K., Lo, P., \& See-To, E. W. (2017). Educational usage of mobile devices: Differences between postgraduate and undergraduate students. The Journal of Academic Librarianship, 43(3), 201-208. Available at: https://doi.org/10.1016/j.acalib.2017.03.004.

Lincoln, Y., \& Guba, E. G. (1985). Naturalistic inquiry. Newbury Park, CA: Sage.

Mahmud, M. M. (2018). Technology and language-what works and what does not: A meta-analysis of blended learning research. Journal of Asia TEFL, 15(2), 365-382. Available at: https://doi.org/10.18823/asiatefl.2018.15.2.7.365.

Mahmud, M. M., Ramachandiran, C. R., \& Ismail, O. (2016). Social media and classroom engagement: Students' perception. Journal of Media Critiques, 2(8), 197-207. Available at: https://doi.org/10.17349/jmc116214.

Mahmud, M. M., \& Wong, S. F. (2018). Facebook and collaborative learning: An empirical study on online assessment. International Journal of Learning and Teaching, 4(2), 107-1 13. Available at: https://doi.org/10.18178/ijlt.4.2.107-113.

Mahmud, M. M., Ubrani, M. B., \& Foong, W. S. (2020). A meta-analysis of blended learning trends. Paper presented at the Proceedings of the 202011 th International Conference on E-Education, E-Business, E-Management, and E-Learning.

Malaysia Education Ministry. (2016). General studies guideline book (MPU). Retrieved from: http://www.ukm.my/ctlt/publication/buku-garis-panduan-pengajian-umum-mpu-edisi-kedua/.

Morris, M. H., \& Liguori, E. (2016). Preface: Teaching reason and the unreasonable. In M. H. Morris \& E. Ligouri (Eds.), Annals of Entrepreneurship Education and Pedagogy (pp. 14-12). Northampton, MA: Edward Elgar Publishing.

Muthuprasad, T., Aiswarya, S., Aditya, K., \& Jha, G. K. (202 1). Students' perception and preference for online education in India during COVID-19 pandemic. Social Sciences \& Humanities Open, 3(1), 100101. Available at: https://doi.org/10.1016/j.ssaho.2020.100101.

Nelson, J. (2017). Using conceptual depth criteria: Addressing the challenge of reaching saturation in qualitative research. Qualitative Research, 17(5), 554-570. Available at: https://doi.org/10.1177/1468794116679873.

Nordin, N. R., Hashim, N., \& Latib, N. A. (2021). Challenges of community college lecturers in implementing online teaching and learning processes. Paper presented at the E-Proceedings of The Green Technology \& Engineering 2020 Virtual Conference GREENTECH'20

Northey, G., Bucic, T., Chylinski, M., \& Govind, R. (2015). Increasing student engagement using asynchronous learning. Journal of Marketing Education, 37(3), 171-180. Available at: https://doi.org/10.1177/0273475315589814.

Nowell, L. S., Norris, J. M., White, D. E., \& Moules, N. J. (2017). Thematic analysis: Striving to meet the trustworthiness criteria. International Journal of Qualitative Methods, 16(1), 1-13. Available at: https://doi.org/10.1177/1609406917733847.

Rahim, A. F. A. (2020). Guidelines for online assessment in emergency remote teaching during the COVID-19 pandemic. Education in Medicine Journal, 12(3), 59-68. Available at: https://doi.org/10.21315/eimj2020.12.2.6.

Szymkowiak, A., Melović, B., Dabić, M., Jeganathan, K., \& Kundi, G. S. (2021). Information technology and Gen Z: The role of teachers, the internet, and technology in the education of young people. Technology in Society, 65, 101565. Available at: https://doi.org/10.1016/j.techsoc.2021.101565.

Walby, K., \& Luscombe, A. (2017). Criteria for quality in qualitative research and use of freedom of information requests in the social sciences. Qualitative Research, 17(5), 537-553. Available at: https://doi.org/10.1177/1468794116679726.

Welch, C. (2018). Good qualitative research: Opening up the debate. In Collaborative Research Design (pp. 401-412). Singapore: Springer.

Windhiyana, E. (2020). The impact of Covid-19 on online learning activities at a Christian college in Indonesia. Educational Science Perspective, 34(1), 1-8.

Yew, O. F., \& Jambulingam, M. (2015). Critical success factors of e-learning implementation at educational institutions. Journal of Interdisciplinary Research Educational, 5(1), 17-24.

Views and opinions expressed in this article are the views and opinions of the author(s), International Journal of Asian Social Science shall not be responsible or answerable for any loss, damage or liability etc. caused in relation to/arising out of the use of the content. 